\title{
PERBAIKAN KUALITAS TIDUR BERDASARKAN POSISI TUBUH SAAT TIDUR MENGGUNAKAN BODY POSITION SENSOR
}

\author{
Theta Dinnarwaty Putri ${ }^{1)}$, Winarno Sugeng ${ }^{2)}$, dan Bintang Candra Ayu Srikandi ${ }^{3)}$ \\ 1,2,3 Jurusan Teknik Informatika, Fakultas Teknik Industri, Institut Teknologi Nasional \\ 1,2,3 J1. PHH. Mustopha No.23, Bandung 40124 \\ E-mail : theta@itenas.ac.id ${ }^{1)}$,winarno@itenas.ac.id ${ }^{2)}$, bcandraas@gmail.com ${ }^{3)}$
}

\begin{abstract}
ABSTRAK
Kebutuhan tidur yang cukup tidak hanya ditentukan oleh faktor jam tidur (kuantitas tidur), tetapi juga oleh kedalaman tidur (kualitas tidur). Baik buruknya kualitas tidur seseorang bergantung pada usaha mereka sendiri untuk mengoptimalkannya, namun banyak pula yang memiliki kualitas tidur yang buruk. Kualitas tidur bisa dideteksi berdasarkan posisi tubuh dengan menggunakan sensor, salah satunya body position sensor. Sensor ini terdiri dari accelerometer yang menghasilkan nilai xaxis, y-axis, dan z-axis. Melalui Arduino diolah nilainya sehingga posisi tubuh dapat dikenali dan dikirim ke sistem. Data ini adalah data yang akan digunakan sebagai nilai posisi tubuh dominan kemudian dicocokkan dengan dataset ilmu kesehatan sehingga mendapatkan hasil kualitas tidur. Apabila hasil kualitas tidur buruk, maka sistem akan mengaktifkan vibration motor untuk mengganggu tidur pengguna, sehingga pengguna berganti posisi. Pada penelitian ini, diperoleh hasil kualitas tidur dimana keluaran setiap pengujian pada beberapa pengguna bergantung pada posisi tidur dominan yang dilakukan pengguna dengan durasi selama satu jam.
\end{abstract}

Kata Kunci: Posisi Tubuh, Accelerometer, Kualitas Tidur, Body Position Sensor

\section{PENDAHULUAN}

Tidur merupakan kebutuhan dasar setiap orang. Pada kondisi istirahat dan tidur, tubuh melakukan proses pemulihan untuk mengembalikan stamina tubuh hingga berada dalam kondisi yang optimal.

Kebutuhan tidur yang cukup tidak hanya ditentukan oleh faktor jam tidur (kuantitas tidur), tetapi juga oleh kedalaman tidur (kualitas tidur). Kualitas tidur meliputi aspek kuantitatif dan kualitatif tidur, seperti lamanya tidur, waktu yang diperlukan untuk bisa tertidur, frekuensi terbangun dan aspek subjektif seperti kedalaman dan kepulasan tidur (Budiono, 2016). Posisi tubuh saat tidur juga ikut menentukan baiknya tingkat kualitas tidur. Posisi tidur miring kanan juga berpengaruh pada kesehatan tubuh karena membuat sistem pencernaan dan sirkulasi darah yang sebagian besar terletak di daerah sebelak kiri bagian tubuh tidak mengalami penekanan. Dr. James B. Mass, 1999 dalam bukunya (Amazon Bestsellers) "Power Sleep: The Revolutionary Program That Prepares Your Mind for Peak Performance", kualitas tidur dikatakan baik jika tidak menunjukkan tanda-tanda kekurangan tidur dan tidak mengalami masalah dalam tidur. Kondisi kurang tidur banyak ditemui dikalangan dewasa muda terutama mahasiswa yang nantinya bisa menimbulkan banyak efek, seperti berkurangnya konsentrasi belajar dan gangguan kesehatan. Baik buruknya kualitas tidur mahasiswa bergantung pada usaha mereka sendiri untuk mengoptimalkannya, namun sebagian besar memiliki kualitas tidur yang kurang baik (Ihsan W., N., 2014).

Penelitian kualitas tidur berdasarkan posisi tubuh dilakukan dengan memanfaatkan Body Position Sensor. Penelitian dilakukan dengan cara mendeteksi posisi tubuh berdasarkan nilai $\mathrm{x}$-axis, $\mathrm{y}$-axis, dan $\mathrm{z}$-axis dengan menggunakan sensor body position kemudian penyocokan dengan ilmu kesehatan sebagai referensi kualitas tidur.

\section{RUANG LINGKUP}

Dalam rangka menjawab permasalahan kualitas tidur yang buruk pada sebagian besar mahasiswa, maka diperlukan sebuah sistem yang dapat mendeteksi kualitas tidur berdasarkan posisi tubuh saat tidur sehingga menampilkan posisi tubuh saat tidur yang paling efisien untuk meningkatkan kualitas tidur (Ihsan W., N., 2014). Berdasarkan uraian latar belakang masalah yang dikemukakan, maka dapat dirumuskan masalah sebagai berikut :

1. Bagaimana sistem mampu membaca posisi tubuh saat tidur.

2. Bagaimana sistem mampu mengidentifikasi kualitas tidur berdasarkan posisi tubuh saat tidur.

3. Bagaimana sistem mampu memperbaiki kualitas tidur berdasarkan posisi tubuh saat tidur. 
Atas dasar rumusan masalah tersebut dilakukan penelitian yang bertujuan untuk membangun sebuah sistem yang dapat memperbaiki kualitas tidur dengan menggunakan posisi tubuh yang dilakukan saat tidur sebagai acuan.

Dalam penelitian yang dilakukan, dibatasi ruang lingkup yang akan dibahas, yaitu sebagai berikut:

1. Menggunakan body position sensor sebagai pendeteksi posisi tubuh

2. Penelitian hanya menggunakan 5 posisi tubuh saat tidur sebagai pendeteksi kualitas tidur, yakni posisi telentang, telangkup, miring kanan, miring kiri dan duduk/berdiri.

3. Penentuan kualitas tidur hanya berdasarkan dari ilmu kesehatan.

4. Penelitian tidak melihat faktor umur, gen, jenis kelamin, temperature, kadar air, dan paparan cahaya pada alat dari pemakainya.

5. Lama waktu pendeteksian posisi tubuh sudah ditentukan sebelumnya.

\section{BAHAN DAN METODE}

Pada bagian ini disampaikan bahan baik bahan peralatan utama maupun pendukung sistem dan metode yang digunakan dalam penelitian dalam hal ini untuk mendukung tujuan penelitian kaitan dengan kualitas tidur termasuk standarisasi dari tidur itu sendiri yang merupakan batasan menentukan nilai dari pada tidur itu yang digunakan dalam metode penelitian. Penentuan batasan tidur dipandang perlu karena belum banyak orang yang memahami yang dinyatakan tidur adalah harus memenuhi kriteria tertentu.

\subsection{Body Position Sensor}

Body position sensor (Gambar 1) merupakan alat yang dapat memonitor posisi badan kepada lima posisi. Alat ini berisikan accelerator yang membaca pergerakan tubuh juga tanda-tanda tubuh seperti temperature, kadar air, juga paparan cahaya pada alat dari pemakainya. Akurasi dari sistem pembacaan pergerakan yang terjadi sangat bergantung pada penempatan dan orientasi dari alat (Hardjadi \& Ihsan., 2017).

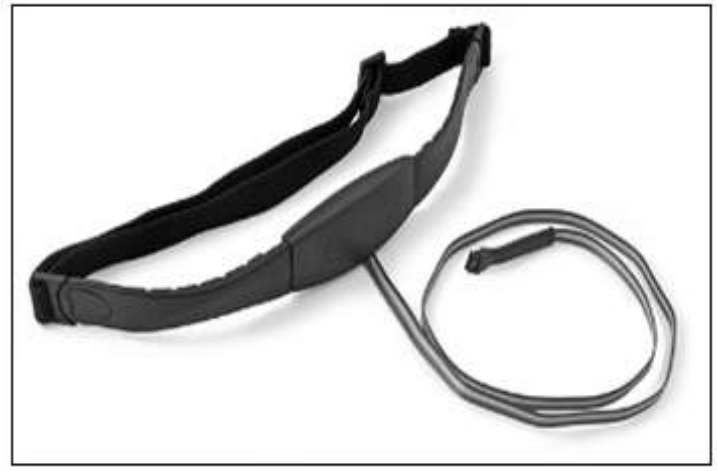

Gambar 1. Body Position Sensor

\subsection{Arduino}

Arduino (Gambar 2) adalah pengendali mikro singleboard yang bersifat open-source, diturunkan dari wiring platform, dirancang untuk memudahkan penggunaan elektronik dalam berbagai bidang. Arduino ini merupakan suatu alat yang cerdas seperti komputer, tapi bentuk yang dimiliki kecil dan harganya yang murah (Setyaningsih, Rozaq \& Solekhan, 2017). Arduino juga merupakan platform hardware terbuka yang ditujukan kepada siapa saja yang ingin membuat purwarupa peralatan elektronik interaktif berdasarkan hardware dan software yang fleksibel dan mudah digunakan (Hardjadi \& Ihsan., 2017).

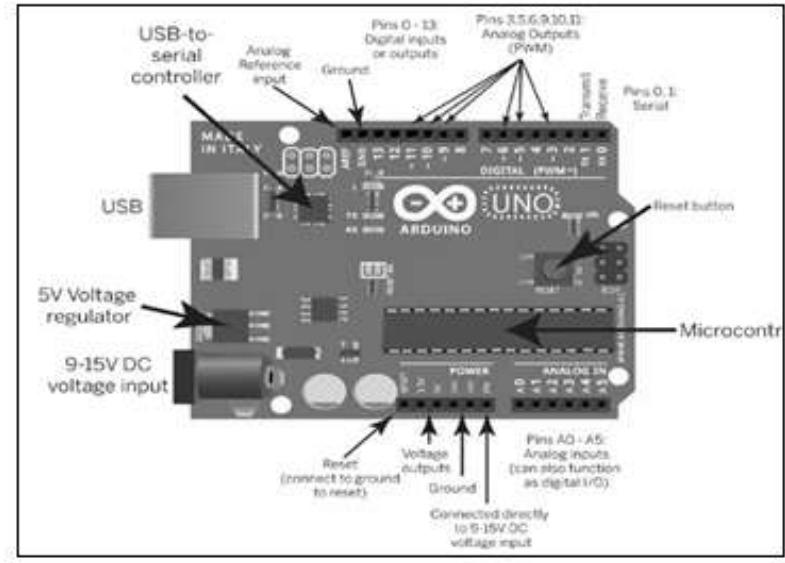

Gambar 2. Struktur bagian Arduino Uno

\subsection{Accelerometer}

Accelerometer adalah perangkat yang berfungsi untuk mengukur akselerasi dengan tepat, jenis akselerasi yang bisadiukur oleh akselerometer adalah akselerasi gaya gravitasi (Riantara, dkk, 2015). Accelerometer mendeteksi pergerakan dari sebuah objek dalam ruang inersia. Accelerometer adalah sebuah perangkat yang mengukur getaran atau percepatan gerak suatu struktur. Setiap posisi accelerometer bereaksi terhadap getaran di sumbu yang berbeda. Output pada alat accelerometer memiliki tiga sinyal, masing-masing mewakili getaran untuk salah satu dari tiga sumbu (Yunita \& Hawa Ju, 2016).

MMA8452 (Gambar 3) adalah accelerometer cerdas, berkekuatan rendah, tiga sumbu, kapasitif, micromachined dengan 12 bit resolusi. Accelerometer ini dikemas dengan fungsi yang disematkan dengan opsi pengguna yang dapat diprogram fleksibel, yang dapat dikonfigurasi ke dua pin interupsi. Fungsi interupsi tersemat memungkinkan penghematan daya keseluruhan yang membebaskan prosesor host dari data pemungutan suara secara terus-menerus. MMA8452 memiliki skala penuh yang dapat dipilih pengguna dari $\pm 2 \mathrm{~g} / \pm 4 \mathrm{~g} / \pm$ $8 \mathrm{~g}$ dengan data yang difilter dengan lintasan tinggi serta data yang tidak difilter tersedia secara real-time. Perangkat ini dapat dikonfigurasi untuk menghasilkan sinyal interupsi wakeup inersia dari kombinasi fungsi 
tersemat yang dapat dikonfigurasi yang memungkinkan MMA8452 untuk memantau kejadian dan tetap dalam mode daya rendah selama periode tidak aktif. MMA8452 tersedia dalam paket 16-pin QFN, $3 \mathrm{~mm}$ x $3 \mathrm{~mm}$ x $1 \mathrm{~mm}$ (Semiconductors, 2016).

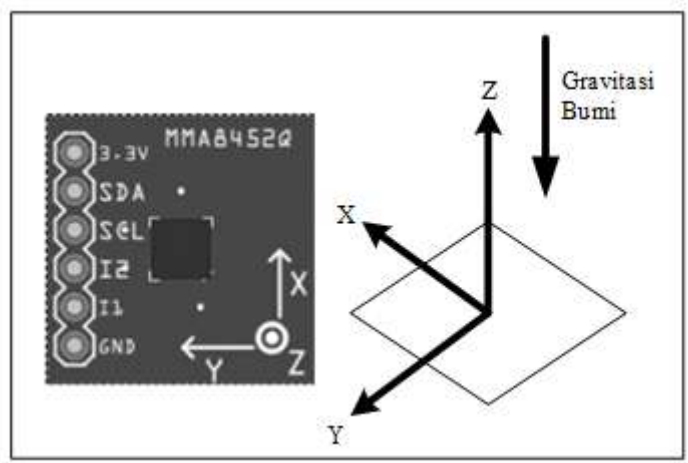

Gambar 3. Accelerometer (MMA8452)

\subsection{Standar Kualitas Tidur}

Kualitas tidur adalah ukuran di mana seseorang mendapatkan kemudahan untuk memulai tidur, mampu mempertahankan tidur, dan merasa rileks setelah bangun dari tidur (Hanifa A, 2016). Kualitas tidur yang buruk dapat disebabkan oleh aktifitas sosial, karena pada usia dewasa muda seseorang sedang berada di puncak keaktifan dalam aktifitas sosial (Sarfriyanda, dkk, 2015).

Kunci penentu kualitas tidur termasuk dalam laporan yang diterbitkan di Sleep Health (Ohayon \& Maurice., 2016), yaitu :

a) Tidur lebih banyak saat di tempat tidur (setidaknya 85 persen dari total waktu).

b) Tertidur dalam 20 menit atau kurang.

c) Terbangun dari tidur tidak lebih dari sekali per malam.

d) Terbangun selama 20 menit atau kurang setelah tertidur.

Sedangkan rentang tidur yang direkomendasikan untuk seluruh usia (Hirshkowitz, 2015) adalah sebagai berikut :

a) Bayi baru lahir (0-3 bulan) : Kisaran tidur 14-17 jam/hari.

b) Bayi (4-11 bulan) : Kisaran tidur $12-15$ jam/hari.

c) Balita (1-2 tahun) : Kisaran tidur 11-14 jam/hari.

d) Anak-anak prasekolah (3-5 tahun) : Jangkauan tidur 10-13 jam/hari.

e) Anak usia sekolah (6-13 tahun) : Kisaran tidur 9-11 jam/hari.

f) Remaja (14-17 tahun) : Kisaran tidur 8-10 jam/hari.

g) Dewasa muda (18-25 tahun) : Kisaran tidur 7-9 jam/hari.

h) Dewasa (26-64 tahun) : Kisaran tidur 7-9 jam/hari.

i) Orang dewasa yang lebih tua (65 tahun keatas): Jangkauan tidur 7-8 jam/hari.

\subsection{Vibration Motor}

Vibration motor adalah alat mekanis untuk menghasilkan getaran. Getaran sering dihasilkan oleh motor listrik dengan massa yang tidak seimbang pada driveshaft. Biasanya, digunakan pada komponen dari produk yang lebih besar seperti smartphone, pager, atau pengontrol permainan video (Akbar \& Yudhana, 2014).

\subsection{Bahan dan Peralatan}

Pada perancangan sistem ini, dibutuhkan beberapa alat, bahan, sera program aplikasi pendukung, yang dikelompokkan menjadi dua bagian, yaitu perangkat keras (hardware) yang terdiri dari Arduino Uno, Accelerometer (MMA8452) dan perangkat lunak (software) yang terdiri dari Netbeans, Arduino IDE.

\subsection{Tahapan Pengembangan Sistem}

Secara garis besar, penelitian ini mempunyai sistem yang akan dibangun melalui beberapa tahapan. Pada Gambar 4 direpresentasikan mengenai alur cara kerja sistem secara keseluruhan berupa blok diagram.

Skema perangkat yang terhubung pada sistem berdasarkan boundering yang telah ditandai sebagai berikut :

1. Posisi tubuh sebagai input yang akan dibaca oleh sistem.

2. Body position sensor digunakan untuk melakukan proses pembacaan posisi tubuh yang akan digunakan dalam pendeteksian kualitas tidur.

3. Sistem digunakan untuk melakukan proses pengklasifikasian posisi tubuh yang telah terhubung dengan body position sensor lalu diterjemahkan menjadi sebuah data hasil.

4. Hasil kualitas tidur didapat dari hasil pencocokan dengan ilmu kesehatan dengan data posisi tubuh dominan data.

5. Peringatan akan dikeluarkan oleh sistem apabila hasil kualitas tidur terdeteksi kurang baik.

Adapun alur cara kerja sistem secara keseluruhan berupa workflow ditampilkan dalam Gambar 5, pada gambar tersebut dijelaskan mengenai interkoneksi dari sistem pendeteksi kualitas tidur berdasarkan posisi tubuh saat tidur sebagai berikut :

1. Melakukan pengambilan objek menggunakan body position sensor untuk mendapatkan data posisi tubuh.

2. Data diterima oleh sistem berupa nilai $\mathrm{x}$-axis, $\mathrm{y}$-axis, z-axis, dan posisi tubuh.

3. Setelah data diterima, dilakukan penyimpanan data pada temporary file berupa file .txt.

4. Seluruh data posisi tubuh diambil kembali dari temporary file dan disortir hasil posisi dominannya. Kemudian dilakukan pencocokan dengan dataset ilmu kesehatan.

5. Proses selanjutnya adalah menampilkan hasil kualitas tidur dari posisi tubuh yang diuji.

6. Terakhir, sistem akan mengaktifkan vibration motor apabila kualitas tidur yang dilakukan terindentifikasi kurang 


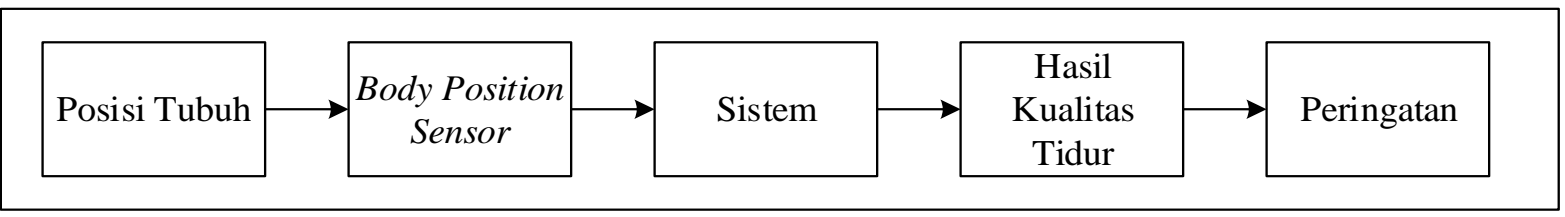

Gambar 4. Blok Diagram Sistem

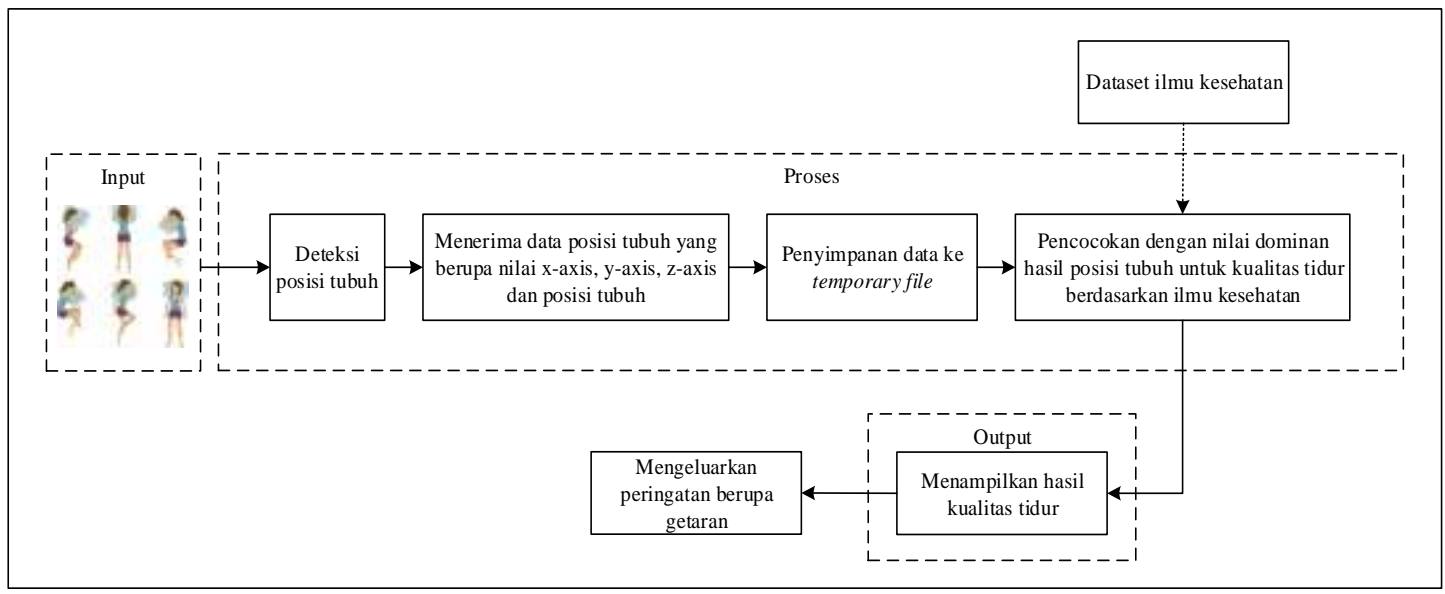

Gambar 5. Workflow Sistem

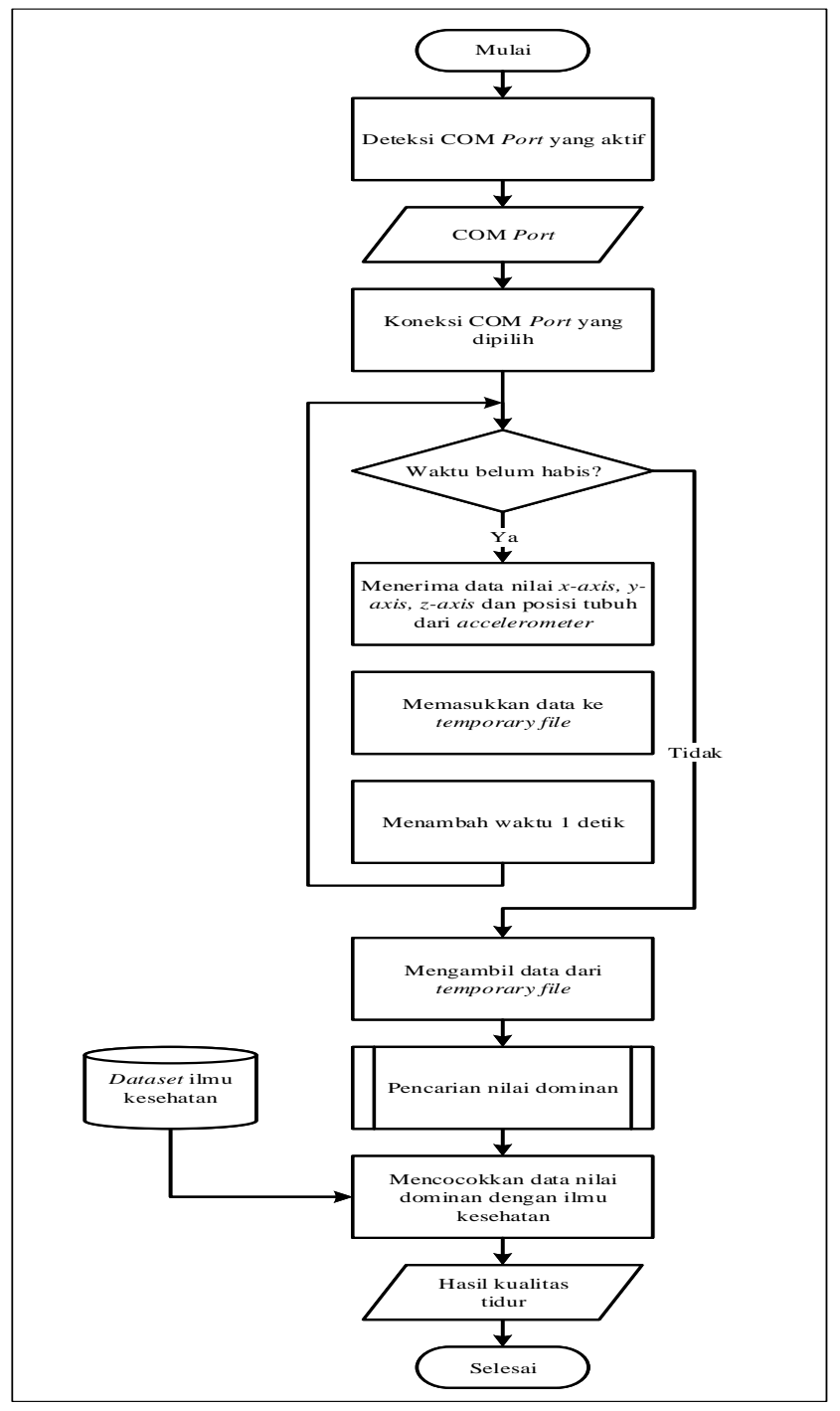

Gambar 6. Flowchart Sistem 


\section{RANCANGAN SISTEM}

Sistem yang dibuat ditunjukkan pada Gambar 6 .

Berikut ini langkah-langkah yang dilakukan :

1. Pemberian inisialisasi durasi lama waktu penelitian, yaitu 1 jam.

2. Sistem melakukan pendeteksian seluruh COM port yang aktif di PC.

3. Kemudian ditampilkan semua port-nya agar bisa dipilih.

4. COMn port yang sudah terpilih dikoneksikan. Hal ini dilakukan agar sistem dan accelerator yang sudah terhubung ke Arduino dapat saling mengirimkan data.

5. Sistem mulai menerima data apabila waktu belum habis. Lama waktu ini ditentukan terlebih dahulu.

6. Setelah data sudah diterima, sistem melakukan penyimpanan data ke temporary file dalam bentuk file berekstensi .txt.

7. Data diambil setiap detiknya. Kemudian waktu secara otomatis melakukan increment 1 detik.

8. Ketika waktu sudah habis, dilakukan pengambilan data dari temporary file yang sudah disimpan sebelumnya.

9. Data yang diambil dilakukan pencarian nilai posisi paling dominan.

10. Dalam dataset ilmu kesehatan mencakup 5 posisi tubuh : posisi terlentang, telangkup, miring kanan, miring kiri, dan duduk/berdiri. Setelah data nilai dominan didapat, dilakukan pencocokan dengan dataset ilmu kesehatan berdasarkan hasil posisi dari nilai dominan. Contohnya, jika nilai dominan adalah telentang, maka diambil dataset ilmu kesehatan posisi terlentang.

11. Hasil dari dataset ilmu kesehatan dipanggil oleh sistem untuk dimunculkan sebagai hasil kualitas tidurnya.

Dalam perhitungan pencarian nilai posisi tubuh dominan ditunjukkan dalam Gambar 7., berikut adalah penjabaran dari subsistem pencarian nilai dominan :

1. Mengambil data posisi tubuh yang ada dalam temporary file.

2. Data posisi tubuh dibaca setiap barisnya mulai dari menit ke-20 yang kemudian dilakukan penambahan +1 pada variabel posisi tubuh yang dideteksi.

3. Ketika data posisi tubuh pada temporary file sudah habis maka dibandingkan setiap nilai variabel posisi tubuh.

4. Setelah didapat variabel posisi tubuh yang paling besar nilainya, diambil nama posisi tubuh sesuai inisialisasi variabelnya. Hasilnya dideklarasikan sebagai nilai posisi tubuh dominan.

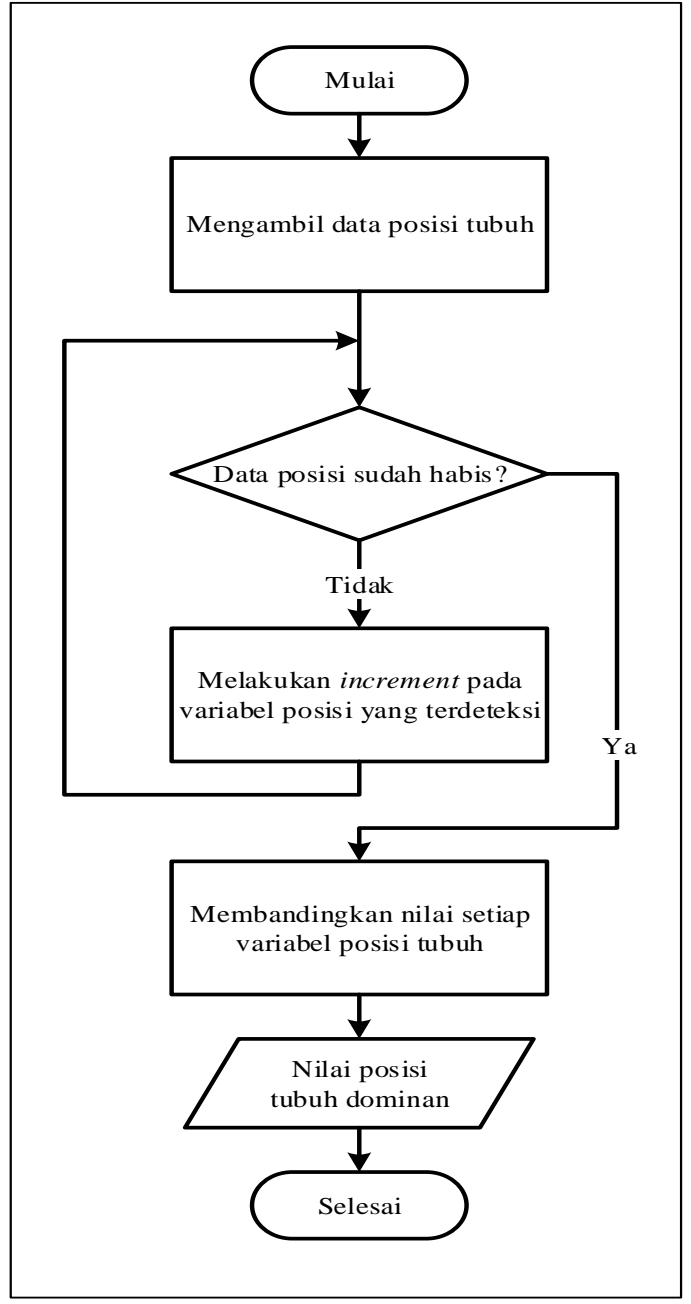

Gambar 7. Flowchart pencarian nilai dominan

\section{IMPLEMENTASI}

Implementasi sistem dilakukan dengan cara menggabungkan perancangan perangkat lunak (software) dengan perancangan perangkat keras (hardware) untuk melakukan pengambilan data posisi tubuh kemudian melakukan pencocokan dengan ilmu kesehatan sehingga dapat mengeluarkan hasil kualitas tidur.

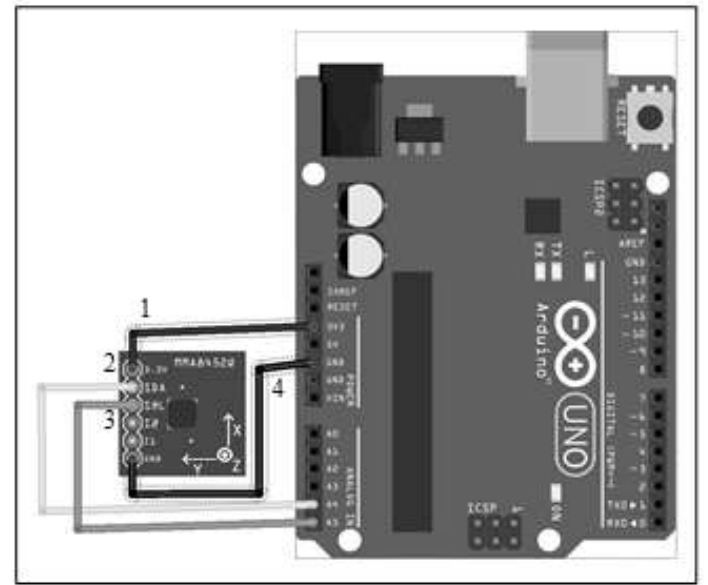




\section{Gambar 8. Interkoneksi hardware}

Pada Gambar 8., ditunjukkan pin interkoneksi antara MMA8452 dan Arduino Uno. Dalam MMA8452, pin yang digunakan adalah $3.3 \mathrm{~V}$, SDA, SCL, dan GND, sedangkan pin Arduino Uno yang digunakan adalah 3V3, GND, Analog 4 dan Analog 5. Pin 3.3V dihubungkan dengan 3V3 yang berfungsi sebagai catu daya (power supply) (garis nomor 1). Pin GND dihubungkan dengan GND yang berfungsi sebagai penetral tegangan (garis nomor 4). SDA dan SCL termasuk dalam bagian Inter Integrated Circuit atau sering disebut $\mathrm{I} 2 \mathrm{C}$ adalah standar komunikasi serial dua arah menggunakan dua saluran yang didesain khusus untuk mengirim maupun menerima data. SDA (Serial Data) digunakan untuk mentransmisikan data, sedangakan SCL (Serial Clock) digunakan untuk menghantarkan sinyal clock sehingga transfer data tersinkronisasi. SDA dihubungkan pada A4 yang berfungsi sebagai serial data pada Arduino Uno (garis nomor 2). SCL dihubungkan pada A5 yang berfungsi sebagai serial clock pada Arduino Uno (garis nomor 3). Data yang ditransmisikan ke Arduino Uno dari MMA4852 berupa data Raw atau dikenal sebagai primary data. Data ini adalah kerja awal dalam sebuah proses pengumpulan data, yang memberikan semua kebutuhan data yang dibutuhkan tanpa diolah maupun dianalisa.

Sedangkan pemakaian sensor body position ditunjukkan pada Gambar 9., Sensor body position dipakai di pinggang dengan posisi sensor di bagian uluh hati. Pemakaian vibration motor diletakkan di bagian leher dan akan memberikan getaran pada leher apabila sistem mengidentifikasi kualitas tidur kurang baik.

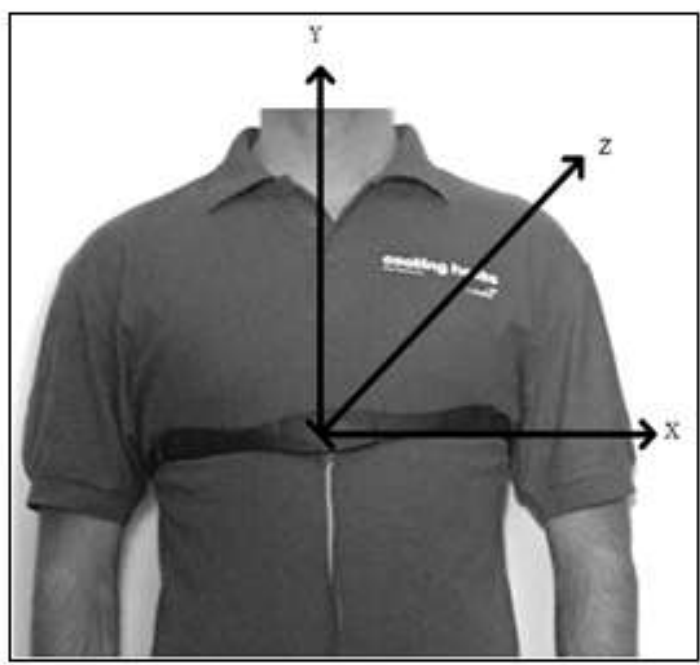

Gambar 9. Pemasangan sensor body position

Pada tahapan pengujian, dilakukan pengecekan apakah sistem sudah dapat menghasilkan output sesuai yang diharapkan pada tujuan penelitian. Output yang dimaksudkan adalah hasil kualitas tidur dari posisi yang terdeteksi. Terdapat 5 posisi tubuh yang dapat dideteksi, yaitu posisi terlentang, telangkup, miring kanan, miring kiri, dan duduk atau berdiri. Skenario pengujian yaitu pengujian dilakukan selama 1 jam terhadap beberapa pengguna.

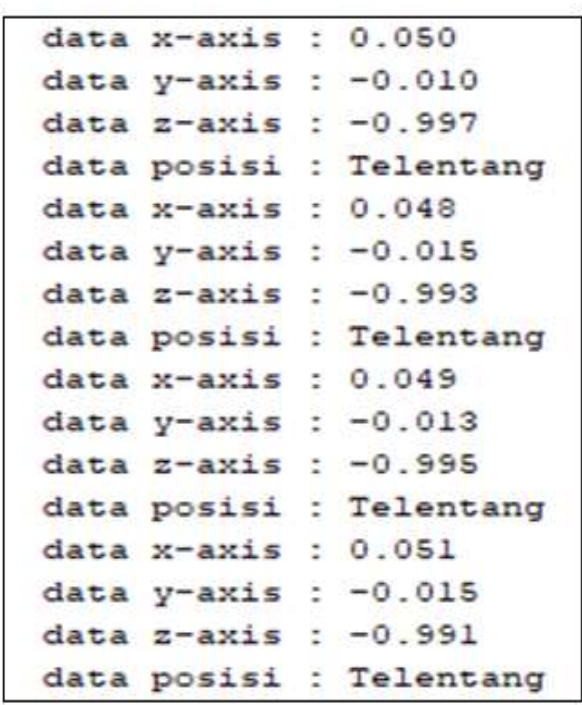

Gambar 10. Keluaran Data Sistem

Pengujian yang pertama dilakukan adalah melakukan penerimaan data untuk memperoleh data yang telah dikirimkan oleh Arduino berupa data nilai xaxis, y-axis, $\mathrm{z}$-axis dan posisi tubuh yang terdeteksi sebelum file disimpan pada temporary file. Apabila sistem berhasil menerima data, maka akan ditampilkan terlebih dahulu di output netbeans. Setiap data baru yang masuk akan terus di update ke dalam temporary file. Keluaran dari sistem yang ditunjukkan pada Gambar 10., menunjukkan data yang berhasil diterima oleh sistem dari body position sensor berupa nilai $\mathrm{x}$-axis, $\mathrm{y}$-axis, $\mathrm{z}-$ axis dan informasi posisi tubuh.

Kemudian pengujian kedua, yaitu pengujian pengambilan nilai posisi dominan dilakukan untuk mencari nilai posisi dominan dengan cara mensortir data posisi tubuh mana yang paling sering muncul berdasarkan temporary file. Nilai perbandingan data posisi tubuh selama 15 menit ditampilkan pada Gambar 11.

Setelah itu sistem akan menampilkan apakah sistem sudah dapat menghasilkan output sesuai yang diharapkan pada tujuan penelitian. Sistem melakukan pencocokan pada dataset dengan nilai posisi tubuh dominan. Berdasarkan skenario pengujian dan nilai perbandingan data posisi tubuh, maka dapat dipastikan hasil kualitas tidur yang muncul sesuai posisi tubuh terlentang.

Pada Gambar 12., ditunjukkan hasil akhir sistem. Sistem mengecek seluruh COM Port yang aktif menggunakan button port. Kemudian list port yang aktif ditampilkan pada combo box. Pada button connect, 
sistem menghubungkan dengan COM Port dari Arduino berdasarkan port yang sudah dipilih di combo box. Untuk memulai penerimaan data, dilakukan dengan cara mengklik button mulai. Label time berisi lama waktu atau durasi selama penelitian. Waktu dihitung setiap detiknya sampai batas waktu yang ditentukan. Button hasil digunakan untuk memanggil temporary file ke sistem didalam tabel informasi data. Informasi ini berisi nilai $\mathrm{x}$-axis, $\mathrm{y}$-axis, $\mathrm{z}$-axis, dan posisi tubuh. Data informasi dihitung nilai dominan posisi tubuh dari menit ke-20 sampai menit ke-60. Hasil perhitungan data nilai dominan dimasukkan dalam text area dibawah tabel. Hasil kualitas tidur ditampilkan dibawah text area yang memuat keterangan keuntungan dan kerugian dari nilai posisi tubuh dominan.

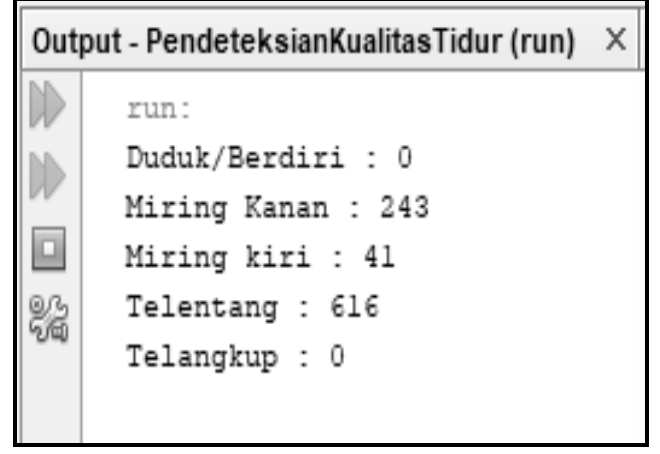

Gambar 11. Data posisi tubuh dominan

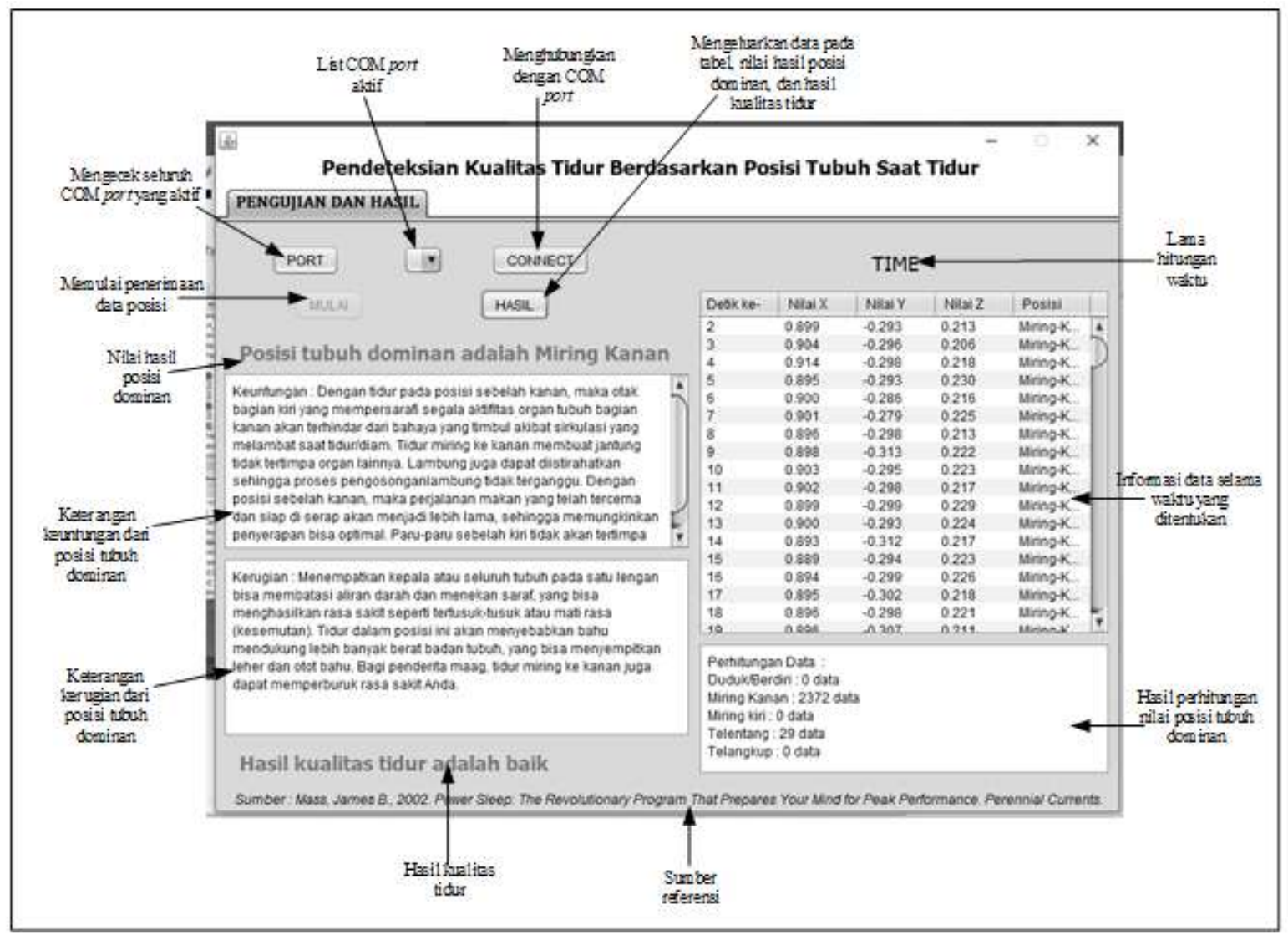

Gambar 12. Output Sistem 


\section{KESIMPULAN}

Berdasarkan penelitian yang dilakukan body position sensor berhasil mendeteksi nilai $\mathrm{x}$-axis, $\mathrm{y}$-axis dan $\mathrm{z}$-axis dan mengirimkannya melalui Arduino ke desktop application. Data nilai dapat diolah untuk diidentifikasi setiap posisinya kemudian disimpan dalam temporary file. Hasil kualitas tidur akan dikeluarkan oleh aplikasi setelah pengidentifikasian data posisi dominan yang kemudian dicocokan oleh ilmu kesehatan. Apabila hasilnya kurang baik, maka vibration motor akan menyala untuk mengganggu tidurnya sehingga mengubah posisi tidur, dalam hal ini tingkat gangguan rendah sehingga tidak berpengaruh terhadap kualitas tidur hanya sebatas mengupayakan berubah posisi.

\section{SARAN}

Untuk pengembangan lanjut dari penelitian ini saran yang dapat diberikan untuk pengembangan penelitian adalah dengan menambahkan sensor pendamping untuk garansi keakurasian posisi tidur, sehingga jika terjadi kesalahan pembacaan body position sensor akibat posisi pada tubuh bergeser maka sensor tambahan dapat melakukan koreksi posisi tubuh.

\section{DAFTAR PUSTAKA}

Akbar \& Yudhana, 2014, Sabuk Getar Sebagai Alat Bantu Penunjuk, Prodi Tek. Elektro, FTI, UAD, Yogyakarta

Budiono, 2016, Konsep Dasar Keperawatan, Pusdik SDM Kesehatan, Jakarta

Hanifa A., 2016, Hubungan Kualitas Tidur Dan Fungsi Kognitif Pada Lanjut Usia Di Panti Sosial Margaguna Jakarta Selatan, Tugas Akhir, Program Studi Ilmu Keperawatan Fakultas Kedokteran Dan Ilmu Kesehatan Universitas Islam Negeri Syarif Hidayatullah, Jakarta

Hardjadi \& Ihsan., 2017, Deteksi Tubuh menggunakan Sensor Body Positio, Itenas Bandung.

Hirshkowitz, 2015, National Sleep Foundation's Sleep Time Duration Recommendations: Methodology And Results Summary, Elsevier Inc.

Ihsan W., N., 2014, Hubungan Antara Kebiasaan Tidur Menurut Islam dan Kualitas Tidur pada Mahasiswa Muslim, Universitas Indonesia.

Ohayon \& Maurice., 2016, National Sleep Foundation's Sleep Quality Recommendations : First Repor, Elsevier Inc.

Riantara, Beta, Cahya \& Darsono, 2015, Aplikasi Sensor Accelerometer pada Handphone Android sebagai Pencatat Getaran Gempabumi secara Online, Jurusan Fisika, FMIPA, Universitas Sebelas Maret, Surakarta

Sarfriyanda, Karim \& Dewi, 2015, Hubungan Antara Kualitas Tidur Dan Kuantitas Tidur Dengan Prestasi Belajar Mahasiswa, Skripsi, Program Studi Ilmu Keperawatan, Universitas Riau
Semiconductors, 2016, MMA8452Q, 3-Axis, 12-Bit/8-Bit Digital Accelerometer.,NXP B.V.

Setyaningsih, Rozaq \& Solekhan, 2017, Efisiensi Beban Smart Home (Rumah Pintar) Berbasis Arduino Uno, Prodi Tek. Elektro, Fakultas Teknik, Universitas Muria Kudus

Yunita \& Hawa Ju, 2016, Studi Keakuratan Pengukuran Getaran Mikro, Teknik Lingkungan, Fakultas Teknik, Universitas Serambi Mekah, Aceh 